\title{
A DÖNTÉSEK LÉLEKTANÁNAK BEMUTATÁSA EGY LABDARÚGÓ TIPPJÁTÉK PÉLDÁJÁN KERESZTÜL
}

THE PSYCHOLOGY OF DECISION MAKING THROUGH A SOCCER BETTING GAME

\section{Boda Márton Attila}

PhD hallgató

Gazdálkodás- és Szervezéstudományi Doktori Iskola, Szent István Egyetem

E-mail: Boda.Marton.Attila.2@hallgato.szie.hu

\section{Összefoglalás}

Egy 2014-es labdarúgó világbajnokság mérkőzéseihez készült tippjátékra érkezett tippek vizsgálatának eredményeit mutatja be a tanulmány. A tanulmányban összehasonlításra került a nemek közötti eredményesség tippelés tekintetében. Megvizsgáltam, hogy van-e összefüggés a tippek leadásának ténye és a végső győzelemre meglévő esély között. Fentieken túl vizsgálat tárgya volt a játékosok kockázatvállalási hajlandósága, illetve, hogy egy korábbi döntés miként befolyásolja a későbbieket.

Kulcsszavak: tippjáték, labdarúgó világbajnokság, kockázatvállalás, lehorgonyzási heurisztika JEL-besorolás: C70, C72, D81

LCC: HB135-147

\begin{abstract}
The study shows the results of an analysis based on a prediction game held during the 2014 FIFA World Cup. In the study a gender comparison was made in case of prediction efficiency. I also analyzed if there is any connection between leaving the game and chances to win it. Risk appetite of the players was analyzed too. It was also part of the research that decisions in the past how influence the future ones.
\end{abstract}

Keywords: prediction game, FIFA World Cup, risk taking, anchoring heuristic

\section{Bevezetés}

A labdarúgó Világ- és Európa bajnokságoknak van némi pozitív hatása a sörfogyasztást illető vásárlói szokásokra (GfK, 2014), mindemellett a különbözö cégek számára is jó marketing lehetőséget jelentenek ezek az események a felfokozott érdeklődés miatt.

Sokan közülük ilyenkor különbözö nyereményjátékokkal próbálkoznak, amelyek közül az egyikkel fogok foglalkozni játékelméleti megközelítésben. A vizsgálatokat SPSS statisztikai programcsomag segítségével végzem el.

A vizsgálat arra irányult, hogy megtudjam, hogyan gondolkoznak a játékosok egy tippjáték során, ahol különböző objektív mérőszámok alapján meghozható döntést érzelmi preferenciák befolyásolnak. A minta elemszáma $n=714$. 


\section{Anyag és módszertan}

\section{A minta bemutatása}

A honlap, ahol a játék futott, akkoriban nem rendelkezett semmilyen pozícionálással ${ }^{1}$ és profillal, a tippjáték volt az első megjelenés. Ezt az információt azért fontos kiemelni, mert így ez a tényező nem befolyásolhatja a továbbiakban olvasott eredményeket.

A játékra történő regisztráció során a játékosoknak csupán egy e-mail címet, illetve egy felhasználói nevet és a saját nevüket kellett megadni. Ennél fogva az elemzéseknél szürőfeltételként csak a felhasználó neme állapítható meg. A játék megkezdése előtt lehetőség volt kitölteni egy 13+1 kérdésből áll kérdéssort, amely a VB különböző eseményeinek kimenetelére, csapatok játékstílusára vonatkozott, amelyből további, elemzést segítő preferenciák tudhatóak meg a játékosok részéről. Habár szürőfeltételként egyes elemeknél nem, de a minta egészéről rendelkezésre állnak leíró adatok, hiszen a játéknak otthont adó honlapról a Google Analytics gyüjt információkat. A rendszer a honlapot látogatókról az elérhető statisztikai adatokat folyamatosan gyüjti.

Ez alapján megállapítható, hogy a VB ideje alatt (2014. június 12. - 2014. július 13.) a felhasználók 14694 munkamenetet indítottak. Ennek a rendszer csak arról a részéról rendelkezik információval, amelyről volt elérhető adat életkorra, nemre vonatkozóan. Azonban tekintve, hogy a teljes sokaság 56,5\%-áról álltak rendelkezésre adatok az életkorra, és 59,5\%áról a nemre vonatkozóan, így várhatóan szignifikáns eltérés nincs a következő adatokban.

A játékosok 40\%-a a 18-24 éves szegmensbe, 47\%-a a 25-34 éves csoportba és csak $13 \%$-uk tartozott az ettől idősebb korosztályba (35-44: 7,8\%, 45-54: 2,9\%, 55-64: 1,7\%, 65+: 0,8\%).

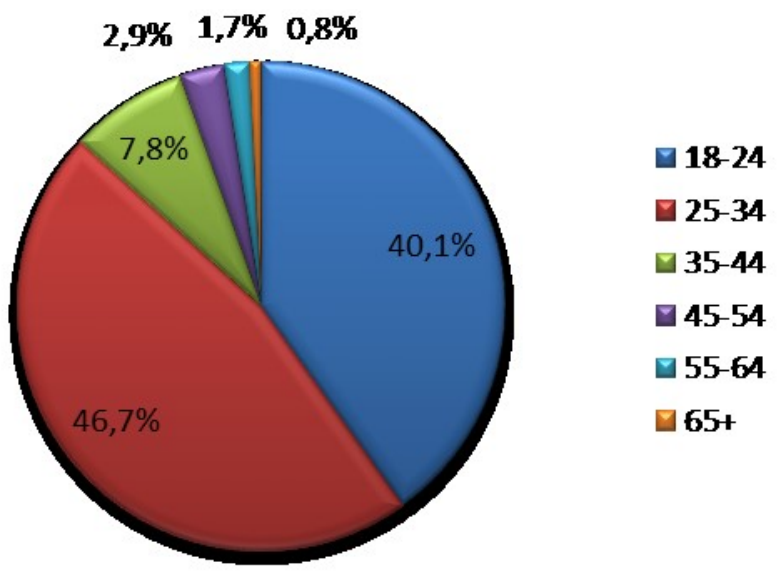

1. ábra: A weboldalon indított munkamenetek százalékos megoszlása korcsoportonként Forrás: saját mérés; GoogleAnalytics

A nemi megoszlást illetően nem okoz meglepetést, hogy egy inkább a férfiak körében népszerü sport esetében az ezzel kapcsolatos játékok is inkább a férfiak között népszerúek. Ennek megfelelően a munkamenetek 74,4\%-át férfiak, míg a 25,6\%-át nők indították, ami megfelel más kutatásokban (Fintor, 2012; Fintor - Szabó, 2012) mért nemek közötti különbségeknek a labdarúgás iránti érdeklődés tekintetében.

\footnotetext{
${ }^{1}$ Nem volt kommunikált termék vagy szolgáltatás, kizárólag a tippjáték futott a weboldalon.
} 
A nemre vonatkozó adatokat manuális úton elő lehetett állítani a játékosok megadott nevei alapján, a keresztnevek felhasználásával. Természetesen az egyes becenevek vagy mủvésznevek használata miatt ez nem minden esetben derült ki (2,1\%), de a többségnél $(97,9 \%)$ ezt egyértelmủen meg lehetett állapítani. Az így képzett nemi arány hasonló a munkamenetek esetében kimutatott számmal: a nemük alapján csoportosítható játékosok 84,2\%-a férfi, míg $15,8 \%$-a nö volt.

A két aránypár $(74,4-25,6 \% ; 84,2-15,8 \%)$ összevetése alapján különböző arányokat látunk. Valószínüleg az aránybeli különbség az általánosan az oldalra tévedő látogatók, de a játékra nem regisztrált felhasználók különbözetéböl ered: minden marketing kampány esetében kell számolni valamekkora meddő szórással, amely esetünkben azt jelentette, hogy a nők között magasabb arányban voltak azok, akik az oldalra tévedtek, de végül érdeklődés hiányában nem regisztráltak egy labdarúgó játékkal foglalkozó tippjátékra.

Mivel rendelkezem a teljes sokaságra vonatkozó adatokkal a nemre vonatkozóan, így a továbbiakban a nemi adatoknál nem a Google által mért, hanem a játékosok neve alapján képzett nemi arányt veszem alapul.

A játékosok földrajzi megoszlása 100\%-ban elérhető adat volt, mivel ezt a rendszer IP-cím alapján rögzíti, ami nyilvános adat, amely alapján pedig a földrajzi elhelyezkedés település szinten is meghatározható. Ez alapján mivel a játék magyar nyelven volt elérhető, nem okoz meglepetést, hogy a munkamenetek 94,1\%-a Magyarországról került indításra. A többi munkamenet vélhetően külföldi magyaroktól származik, többségében EU országokból, de jelentős arányuk az Amerikai Egyesült Államokból jelentkezett be. Magyarországon belül erős főváros központúság figyelhető meg: a munkamenetek 59,6\%-át Budapestről indították. Ezen kívül még Pest megye volt kimagasló a megyék közül: 9,4\%-ot ért el. A többi megye 4,2\% (Komárom-Esztergom) és 0,3\% (Nógrád) között szóródott, lefedve az összes megyét.

Bár a döntéseket nem befolyásolta, csupán érdekesség, hogy a munkamenetek 72,2\%-át asztali számítógépröl, 24,1\%-át mobilról, míg 3,7\%-át tabletről indították.

\section{A játékszabályok, a pontozás metodikája}

A játék szabályzata viszonylag egyszerü volt: a VB egyes mérkőzéseinek eredményét kellett megtippelni a pontos végeredmény megjelölésével. A pontozás alapvetően a mérkőzés kimenetelének eltalálását értékelte a legmagasabb pontszámmal (6 pont), de a rúgott gólok közötti távolság eltalálása (1 pont) és a rúgott gólok száma (3 pont) is befolyásoló hatással bírtak.

A pontverseny kezdetén kellett választani egy csapatot, amely a játékos szerint megnyeri a VBt. Erre további pluszpontokat tudott gyüjteni a játékos helyes tipp esetén. A későbbiekben az adott csapatot választó játékosokat az egyszerüség kedvéért a csapatnak szurkolónak fogom titulálni, noha ez nem feltétlenül jelenti a hétköznapi értelemben vett tényleges szurkolást is.

A cél a játék során minél több pont gyüjtése volt a VB 64 mérkőzése alatt. A pontversenyben kialakult sorrend alapján a játékosok kisebb értékü ${ }^{2}$ nyereményekkel lehettek gazdagabbak.

\footnotetext{
${ }^{2}$ pl. étel és italfogyasztásra jogosító kuponok
} 


\section{A mérközések végeredményének valószinüsége}

A mérkőzés kimenetelének eltalálására két azonos szintü, tudású és formájú csapat esetén 1/3 lenne a valószínüség, hiszen 3 lehetséges kimenetele van a mérkőzésnek (egyik csapat győzelme, döntetlen, másik csapat győzelme). Azonban, ahogy a tökéletes versenypiac elmélete is csak papíron létezik, úgy két tökéletesen egyforma csapat sincs. Bár hasonló tudásúak lehetnek, mégis tudunk eltérö mértékü esélyeket rendelni az egyes csapatok győzelméhez.

A várható végeredményre csak nagyon bonyolult mutatókkal lehet közelíteni és a legösszetettebb mutatórendszer sem tud megbízható eredményt adni, így helyesebb feltenni úgy a kérdést, hogy az emberek milyen eredményre számítanak? Ebben az esetben helyettesítettük az eredeti kérdést és egy egyszerübb kérdés megfogalmazásával tettük megválaszolhatóvá azt. Ezzel a témával részletesen foglalkozik Kahneman (2011, pp. 115-126). Így már egy könnyebben mérhető, egzakt formában kifejezhető számot kapunk, amely ráadásul a játékosok számára is könnyen hozzáférhető. Ez a mutatószám pedig nem más, mint a fogadóirodák által megállapított „megtérülési viszonyszám”, vagyis odds, ami az egyes eseményekhez rendelhető valószínüségként funkcionál.

Az odds helyett számos faktort bevonhatnánk a kérdés megválaszolásához, például a historikus adatok vizsgálatával a korábbi mérkőzések eredményeinek összevetése a két csapat között, vagy a világranglistán elfoglalt helyezések közötti távolság, akár a csapatok játékosállományának becsült, pénzben kifejezett értéke, de a leggyorsabb és legmegbízhatóbb eredményre a fogadóirodáknál leadott tippek vezethetnek. A fogadóirodáknak alapvetően magas az elörejelzési képessége a bizonytalan jövőt illetően, hiszen rosszul megállapított oddsok, megtérülési viszonyszámok mellett hamar csődbe mennének (Spann - Skiera, 2009). Tehát vegyük alapul a továbbiakban az egyes mérkőzések kimeneteli eredményének a fogadóirodák által megállapított oddsokat. Az odds természetesen tartalmazza a fogadóiroda nyereségét is, de a kimenetelek egymáshoz viszonyított arányából már egy körülbelüli értéket lehet rendelni a várható kimenetelekhez, mint valószínüséget.

\section{Kialakitható-e racionális stratégia?}

A Nash egyensúly lényege, hogy ha ismernék a játékosok az ellenfelek várható döntését, akkor bizonyos számú iteráció után kialakul egy olyan döntéshalmaz, amelyen egyik játékos sem változtatna (Nash, 1950). ${ }^{3}$ Klasszikus példa erre az úgynevezett nemek harca, amelyben egy pár két tagja eltérő szabadidő eltöltésben érdekelt, de egyszerre igaz az is, hogy a legmagasabb az időtöltés hasznossága, ha egymással töltik azt és mindkét fél számára rosszabb, ha külön vannak. A nemek harca hasonlít a fogolydilemmához, azzal a különbséggel, hogy itt a párok nem egymástól elszigetelten kell, hogy döntsenek az alternatíváik között.

\footnotetext{
3 A játékelméletben Nash-egyensúlynak nevezzük a részt vevő játékosok egyéni stratégiáinak olyan stratégia együttesét, amelyre igaz, hogy minden egyes játékos aktuális stratégiája egy parciálisan legjobb választ ad a többi játékos aktuális stratégiájára. Pontosabban: amennyiben a többi játékos egyike sem változtat az aktuális stratégiáján, akkor az adott játékosnak sem érdemes változtatnia, mert nem járna jobban a változtatással. (Nash, 1950)
} 


\section{1. táblázat: A várható hasznosság táblázata egy nemek harcára kitalált példa esetén}

$\begin{array}{lcc} & \text { Sára meccset néz } & \text { Sára sétálni megy } \\ \text { Kornél meccset néz } & 3,2 & 1,1 \\ \text { Kornél sétálni megy } & 0,0 & 2,3\end{array}$

Forrás: Saját szerkesztés

Látható, hogy amennyiben ismerik a másik fél döntését, úgy biztosan adható olyan döntés, amellyel a lehető legjobban jár a másodikként döntő, tehát alkalmazkodó fél, és az első sem változtatna az eredeti döntésén. Például ha Sára eldöntötte, hogy sétálni megy, Kornél akkor jár a legjobban, ha ö is vele tart. A döntésén Sárának sem érdemes változtatnia.

A tanulmányban vizsgált tippjáték esetén ez nem mondható el, mert a ranglétra más-más fokán állók különböző stratégiában érdekeltek. Az élenjárók előnyének megtartását a jó tippelés mellett az is fenntartja, ha ugyanazt tippeli, mint a következő játékosok. Ezzel szemben a lemaradt játékosoknak a helyes tippelés ténye önmagában már nem elegendö, hiszen ha ugyanazt tippelik, mint az elötte álló játékos, akkor csak konzerválják a különbséget. Ilyenformán, ha a játékosok ismernék egymás tippjeit, az első helyezettek folyton az utánuk következők tippjeit adnák le, míg az utána lévők folyton eltérő tippre törekednének, amennyiben feltételezzük, hogy a ranglétrán elfoglalt helyezés maximalizálása a racionális játékosok célja.

A játékosok elöre nem tudják az ellenfeleik döntését, csupán a ranglétrán elfoglalt helyüket, a pontszámukat és a mérkőzésről is ugyanolyan információval rendelkeznek, ami a végkimenetelt illeti. Habár az ellenfelek döntése elöre nem ismert, mégis lehet következtetni arra. Hasonló helyzetet ír le a Keynesi-szépségverseny is ${ }^{4}$, ahol nem az a megfelelő válasz, hogy az olvasó kit tart szépnek, hanem, hogy az olvasó mit gondol, a többi olvasó kit tart szépnek (Keynes, 1936). Az élen álló játékosnak már az is jó eredménynek számít, ha nem csökken a pontszámban kifejezett távolság az őt követő játékosok és saját maga között. Ennél fogva számára az előnyös, ha a lehető legmagasabb valószínűséggel bekövetkező eseményt tippeli meg, hiszen amennyiben az ellenfelei is így tesznek, az előnyét megörzi, amennyiben pedig ellenfelei másként tesznek, úgy nagyobb lesz az esélye a távolság növekedésére, mint a csökkenésére.

Az egymással versengőknek hasonló eredményre kellene tippelnie, amennyiben elfogadjuk egyes eredményekről, hogy azoknak ténylegesen magasabbak a bekövetkezési valószínüségei.

Mivel az ellenfelek döntése elöre nem ismert, ezért helyesebb lenne a nemek harca helyett a fogolydilemma oldaláról megközelíteni a kérdést. Kitalált példánkban az A és $\mathrm{B}$ csapat győzelmére lehet tippelni, ahol fogadjuk el, hogy az A csapat győzelmének $60 \%$, míg a B csapat győzelmének $40 \%$ esélye van. Ha 10 pontot adunk a helyes találatra, akkor a várható érték is könnyen megállapítható.

\footnotetext{
${ }^{4}$ A példában egy lapban 100 szép nő közül kell megtippelni a 6 legszebbet. A díjat az kapja, akinek a tippjei a legközelebb esnek az összes válaszadó által adott átlagos válaszhoz.
} 
2. táblázat: A várható értékek táblázata egy fiktív sporteseményre érkező tippek esetén, ahol A csapat győzelmi esélye $60 \%$, B csapaté $40 \%$, és a helyes tippre járó pont értéke 10 pont

Sára A csapat győzelmére tippel 6,6 4,6
Sára B csapat győzelmére tippel 6,4

4,4

Kornél B csapat győzelmére tippel

Forrás: Saját szerkesztés

Ez alapján egyértelmü lenne, hogy az A csapat győzelmére kellene fogadnia Sárának és Kornélnak is, ha ez az egyetlen mérkőzés, és pontegyenlőség van a felek között. A játékosoknak a fenti okfejtésből láthatóan nincs különleges stratégiai választási lehetősége, egyszerüen a lehető legvalószínübb eredmény megtippelése a helyesen megválasztott cél.

A valószínűségek azonban szubjektívek. Azt, hogy mennyire bizonytalanok a labdarúgó mérkőzések kimenetelei, jól bizonyítja, hogy paradox módon a futball szakértők sem képesek jobb valószínüséggel tippelni helyes eredményeket, mint az e téren korlátozott tudással rendelkezők (Andersson et al., 2005). Az olyan kiemelt labdarúgó eseményeken pedig, mint a Világ- vagy Európa-bajnokság, eleve selejtező sorozatot végigjárt csapatok vesznek részt, így a különbség az egyes csapatok között kisebb, mint ha a világ kettő, véletlenszerüen kiválasztott csapatát játszatnánk együtt, amely csak tovább nehezíti, hogy egyértelmüen megállapíthatóak legyenek a győzelmi esélyek.

\section{Eredmények}

\section{A férfiak vagy a nök tippelnek jobban?}

Feltételezhetően nincs különbség a tippelés eredményességében a nemek között, de érdemes ezt a tényleges számok tekintetében is megvizsgálni.

Kereszttáblás elemzést használtam, mert kíváncsi voltam arra, hogy bár az érdeklődés foka magasabb volt a férfiak körében a játék iránt, de vajon „a focihoz való értésük” is magasabb szinten áll-e a női játékosokhoz képest? A kérdés itt azért érdekes, mert általánosan megfogalmazva a kérdést egy átlagos férfi egy átlagos nőnél jobban ért egy olyan sporthoz, ami jóval több férfit érdekel mint nőt, azonban itt egy speciális esetről van szó, hiszen a kérdést úgy kell vizsgálni, hogy a labdarúgás iránt pozitív attitüdöt mutató nők vagy férfiak csoportja lesz eredményesebb a játékban, hiszen alapvetően ilyen játékosok regisztráltak, nemtől függetlenül.

A változók vizsgálatára egy Khi-négyzet próbát végeztem. 704 elem maradt a vizsgálatban az után, hogy 10 elem kizárásra került amiatt, hogy nem volt egyértelmüen eldönthető a játékos neme. A leadott tippek és a nem közötti összefüggés az alábbi táblázatban került vizsgálatra. 


\section{3. táblázat: Khi-négyzet próba a leadott tippek és a játékosok neme közötti összefüggésre}

\begin{tabular}{|l|r|r|rr|}
\hline & Érték & \multicolumn{2}{|c|}{$\begin{array}{c}\text { Szabadságfok } \\
(\mathrm{df})\end{array}$} & $\begin{array}{r}\text { Aszimptotikus szignifikancia } \\
\text { (kétoldali) }\end{array}$ \\
\hline Pearson féle Khi-négyzet próba & $63,589^{\mathrm{a}}$ & 62 &, 420 \\
\hline Valószínúségi arány & 73,413 & 62 & &, 152 \\
\hline Érvényes esetek száma & 703 & & & \\
\hline
\end{tabular}

a. $91(72,2 \%)$ azon cellák száma, amelyek várható értéke kisebb mint 5

Forrás: saját mérés; SPSS program által készitett táblázat

A szignifikancia szint 0,05 felett van, így gyakorlatilag az állapítható meg, hogy nincs olyan kapcsolat a nem és a leadott döntések száma között, amely ne lenne akár a véletlennek köszönhető, így a Cramer mutató számítása már nem is volt indokolt (3. táblázat). Ugyancsak nincs szignifikáns különbség a nemek tekintetében az elért pontokban sem (4. táblázat).

4. táblázat: Khi-négyzet próba a tippjátékban elért pontok és a játékosok neme közötti összefüggésre

\begin{tabular}{|l|r|r|rr|}
\hline & Érték & \multicolumn{2}{|c|}{$\begin{array}{c}\text { Szabadságfok } \\
(\mathrm{df})\end{array}$} & $\begin{array}{c}\text { Aszimptotikus szignifikancia } \\
\text { (kétoldali) }\end{array}$ \\
\hline Pearson féle Khi-négyzet próba & $269,569^{\mathrm{a}}$ & 239 &, 085 \\
\hline Valószínủségi arány & 253,161 & 239 &, 253 \\
\hline Érvényes esetek száma & 703 & & & \\
\hline
\end{tabular}

a. $452(94,2 \%)$ azon cellák száma, amelyek várható értéke kisebb mint 5

Forrás: saját mérés; SPSS program által készitett táblázat

Megállapítható, hogy ugyan az érdeklődés mértéke alacsonyabb fokon áll a labdarúgást érintő tippjáték esetében a nőknél, azonban akiket érdekelt a játék, nem tippeltek szignifikánsan rosszabbul, mint férfi társaik.

Van összefüggés az elért pontszám és a döntés leadása között?

Feltételezem, hogy győzelem esélyének csökkenésével csökken a tippelési kedv is, illetve minél több az elért pontszám, annál nagyobb a valószínüsége, hogy az adott körben leadásra kerül döntés. Ennek érdekében a döntések leadásának tényét vizsgáló grafikont (2. ábra) érdemes elemezni.

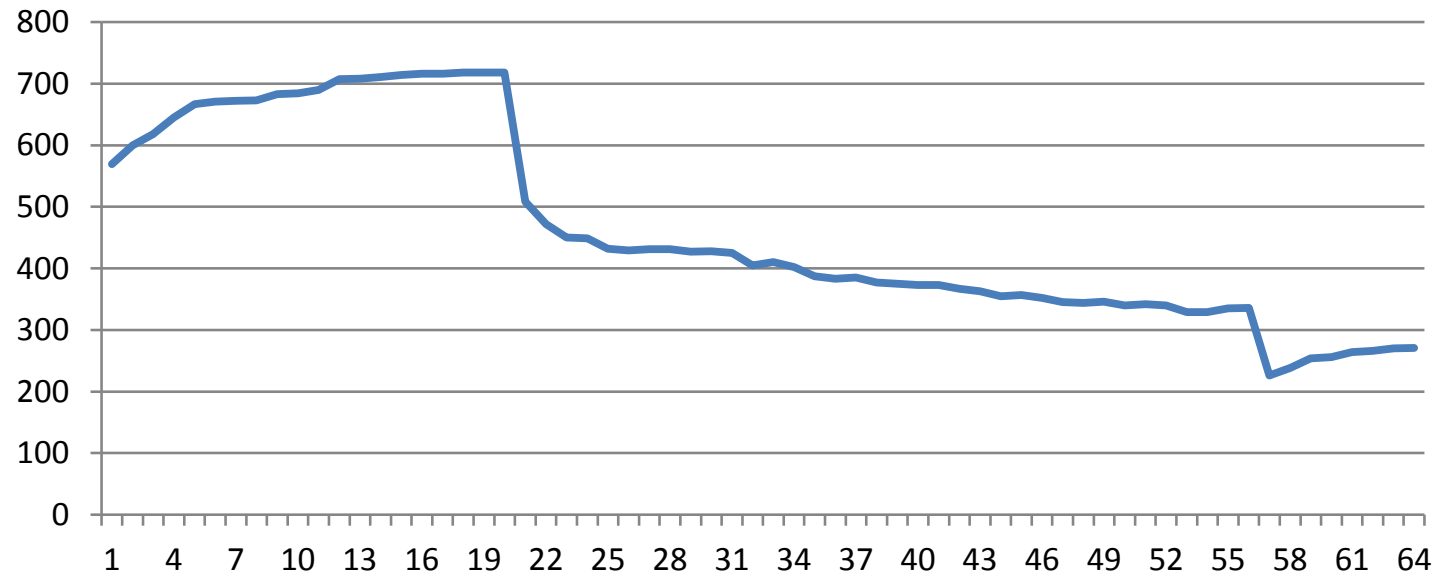

2. ábra: A leadott döntések számának alakulása mérkőzésenként

Forrás: saját mérés 
Az első nagy visszaesés a huszadikról a huszonegyedik mérkőzésre látható a grafikonon. Ennek egyik lehetséges magyarázata lehet, hogy a spanyolok Chile elleni vereségét követően biztossá váló kiesésükkel sok spanyol válogatottnak szurkoló játékos már lemondott a további játékról. Ennek érdekében célszerü összevetni a spanyolokra tippelő játékosok tippleadási arányának változását a nem spanyoloknak szurkoló játékosokéval (3. ábra).

A grafikonon látható, hogy az elmélet nem igazolható a spanyolok kiesésével, hiszen a más csapatokat választó játékosok tipp-leadási kedve is erősen visszaesett a 21. körben. Az ábrán még egy nagy törés látható az 56. körről az 57. körre. Ez nagy valószínüséggel annak volt köszönhető, hogy az 56. mérkőzés (Belgium-Amerikai Egyesült Államok) után legközelebb csak 3 nappal később játszottak mérkőzést, ami azt eredményezte, hogy néhányan „megfeledkeztek a játékról”. Ezt támasztja alá az is, hogy ezután ismét növekedni kezdett a tippleadások aránya.

Miután nem állítható, hogy valamely csapat kiesése indokolta volna az első visszaesést, ezért csak a lebonyolítási rend okolható érte. Mégpedig konkrétan ez azt jelenti, hogy nem volt elérhető a játékot bonyolító felületen a teljes mérkőzéskínálat a játék indulásakor, hanem mindig csak egy meghatározott mennyiség. Ez a játék indulásakor az első 20 mérkőzést jelentette. Azok tehát, akik a játék elején csatlakoztak, de elvesztették az érdeklődésüket, vagy egyszerüen csak megfeledkeztek a játékról, már nem léptek vissza az oldalra megtenni a 20. mérkőzés utáni tippjeiket.

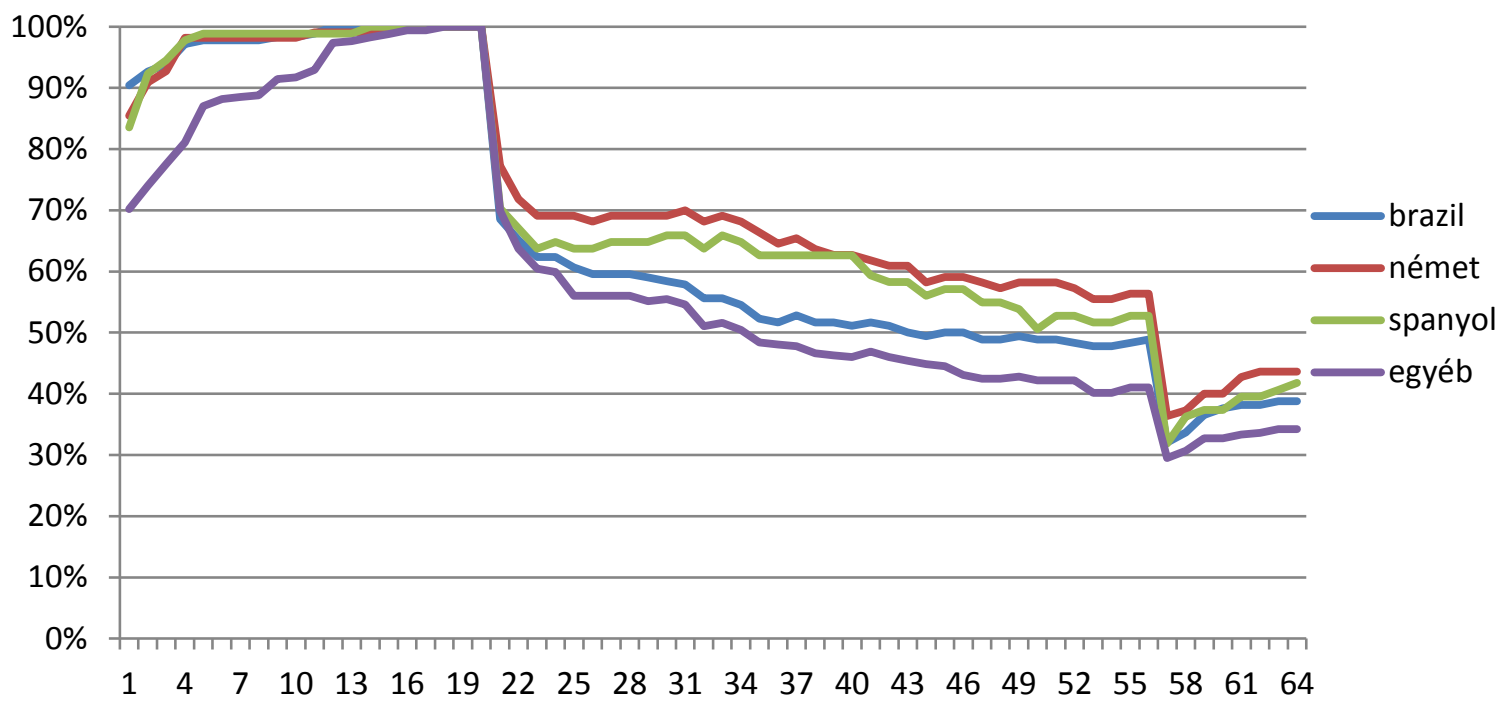

3. ábra: A mérkőzésekre leadott tippek arányosítva kedvenc válogatottanként $(\mathbf{1 0 0 \%} \%=$ legtöbb leadott tipp)

\section{Forrás: saját mérés}

Önmagában tehát a kedvenc csapat kiesése még nem jelenti, hogy emiatt otthagyják a játékosok a játékot. Annak érdekében, hogy kiderítsem, hogy a vártnál gyengébb szereplés miatt hagynake fel a játékkal a játékosok, kereszttáblás elemzést végeztem a pontszámok és a döntés leadásának ténye között.

Ehhez megvizsgáltam, hogy az egyes játékosok hány körig adtak le folyamatosan döntéseket, majd meghatároztam azoknak a körét, akik onnantól, hogy egyszer nem tippeltek, már a játék végéig nem tippeltek, tehát ténylegesen felhagytak a játékkal, nem csak néhány mérkőzés erejéig. Ehhez a csoporthoz még hozzávettem azokat, akik végigjátszották a játékot, így összesen ilyen játékosokból a teljes tippelő állományban $(n=714)$ 415-öt találtam. Ezen felül 
még egy korlátozással éltem: a játékkal a 21. és 57. körben felhagyó játékosokat kivettem a további elemzésekből, hiszen ahogy a korábbi elemzésekből kiderült, esetükben más hatás dominált. Így összességében 298 adatsor maradt az elemzésekhez. Ahhoz, hogy ennyi adatból értékelhető minőségű elemzés készüljön, nem csökkenthettem még tovább az egyes körökben összehasonlítható adatok körét: az eredeti elképzelés szerint ugyanis körönként hasonlítottam volna össze a játékkal felhagyók és játékot folytatók pontjait az utolsó olyan körben, amikor még mindkét csoport adott le döntést, és így vizsgáltam volna, hogy van-e összefüggés az elért pontok (és így a helyezés), valamint a játék felhagyása között. Mivel körröl körre változott a pontszám, az alábbi módszert vezettem be: az elért pontszámot minden egyes körben arányosítottam: az élen álló játékos $100 \%$-os értéket kapott, míg a többiek a pontjaikat az első helyen álló játékos pontjaihoz viszonyítva, annak arányában kapták a százalékos értéket.

Az adatokat 2 csoportra (játékkal felhagyók és tovább játszók) osztva azt kaptam, hogy a játékkal felhagyók jóval kevesebben voltak a játék során, amely nehezítette az adatok összehasonlíthatóságát. Nem is lehetett körröl-körre megvizsgálni a kapcsolatok szorosságának alakulását, össze kellett vonni több kört is. Ez alapján bár a kisszámú adat miatt többször nem tudott kapcsolatot kimutatni az elemzés, de összességében az volt megállapítható, hogy a játék elején (első 20 kör) gyengébb volt a kapcsolat az elért pontszámok és a tippelési kedv között (0,3-0,5), míg a játék középső szakaszában (22-35. kör) közepesnél erösebb $(\sim 0,6)$ és a játék vége felé (36-63. kör) már közepesen erös kapcsolat $(0,7-0,8)$ volt jellemzö.

Annak az oka, hogy az első 20 körben gyengébb a kapcsolat indokolható egyrészt azzal, hogy (1) az esélyek a végső győzelemre még nyitottabbak, mint a későbbiekben, amikor már jobban körvonalazódik, hogy ki esélyes a végső győzelemre, illetve

(2) azzal a korábban már felvázolt ténnyel, hogy az első 20 körre egyszerre le lehetett adni tippet, és megvolt az esélye annak, hogy a játékos később ne térjen vissza, "elfelejtse", hogy egy tippjátékban vesz részt.

Mivel az elemzésből kivettem azokat a játékosokat, akik a 21. körben hagytak fel a játékkal, így esetünkben a (2) megállapítás nem marad helytálló.

Összességében az állapítható meg, hogy annak a hatása, hogy a pontszámok függvényében abba hagyja-e egy játékos a játékot vagy sem, attól függ, hogy van-e még esélye a végső sikerre, mivel minél közelebb voltunk a játék befejezéséhez, annál erősebb volt a kapcsolat a játszás/játékkal felhagyás ténye és a pontszámok mértéke között.

\section{Alacsony fokú változatosság a tippekben}

Ebben a fejezetben arra a kérdésre kerestem a választ, hogy van-e gyakori eredmény, és ha igen, akkor az mekkora hányadot tesz ki játékosonként, mennyire jellemző ez a tippelésekre összességében?

Első körben azt vizsgáltam, hogy a játékosok hányféle tippet adtak le.

Mivel nem minden játékos adott le minden mérkőzésre tippet, ezért célszerü volt a tippek sokféleségét darabszámok helyett arányszámokkal kifejezni. Azonban veszélyt jelenthet, hogy könnyebb az összes leadott tipp arányában nagyarányú „sokszínűséget” elérni alacsonyabb tippszám mellett. Ezért először meg kellett vizsgálni az adatokat az SPSS program segítségével, hogy a leadott tippek száma és a tippek változékonyságának aránya (különböző tippek száma / 
összes leadott tipp) között fennáll-e kapcsolat, mekkora az a sáv, amelyet úgy használhatunk, hogy már nem torzít a fentebb kifejtett hatás.

A vizsgálat elvégzésének szükségességét 2 feltételezés adja:

- $\quad$ ha egy játékos 1000 különböző labdarúgó mérkőzésre tippel, a realitás keretei között nem fog 1000 különböző eredményt tippelni

- ha elérünk egy bizonyos mennyiségű mérkőzésszámot (és a hozzá tartozó tippet), a különböző mérkőzéseredmények száma nem fog szignifikánsan növekedni.

Alapvetően a 2. állítás számunkra a fontosabb és az SPSS elemzéstől ennek a számnak a megtalálását várom a játékosállomány tekintetében.

Az adatokat tehát be kellett vinni az SPSS statisztikai elemző programba, és meg kell nézni, hogy van-e bármilyen irányú korreláció. A várt eredmény az volt, hogy minél alacsonyabb a tippmennyiség, annál nagyobb lesz az esélye a homogén tippeknek.

A vizsgálat az alábbi eredményeket hozta. Azokat az elemeket vettem csak számításba, ahol érkeztek érvényes tippek: 714 ilyen elem volt. Amennyiben a teljes tippelö állományt vizsgálom, úgy megállapítható, hogy a megtippelt mérkőzések száma és a tippek változékonyságának aránya között a várakozásoknak megfelelöen erős negatív Spearman féle rangkorrelációs együttható volt kimutatható, értéke -0,906, tehát a kevesebb tippszám kevésbé változatos tippeket, míg a magasabb leadott tippmennyiség változatosabb tippeket jelent. Eddig tehát a várt eredményeket igazolja az elemzés. Elkezdtem növelni a minimálisan leadott tippek számát azok körében, akiket bevettem a vizsgálatba. Ennek az eredményei láthatóak az 4. ábrán.

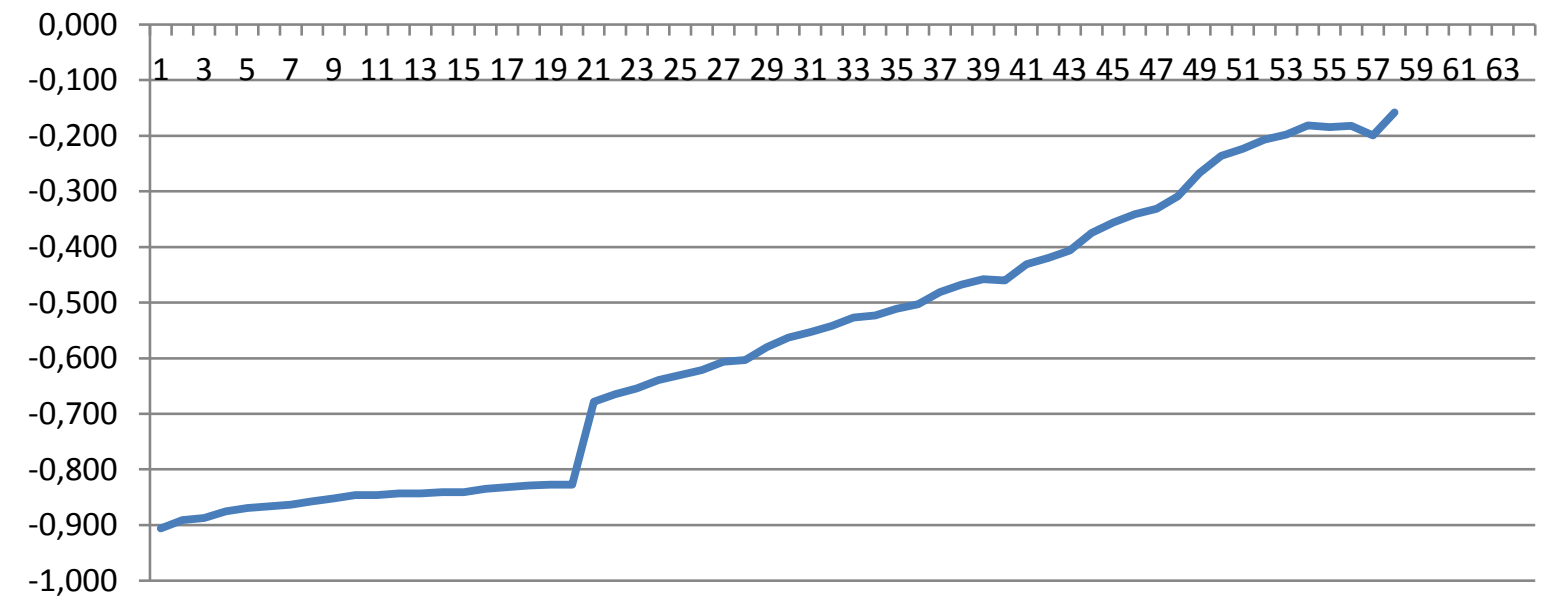

\section{4. ábra: Korreláció (y tengely) a leadott tippek száma és a tippek változékonyságának aránya között a minimálisan leadott tippek (x tengely) növelésével}

Forrás: saját mérés, SPSS programcsomaggal

A 21. körnél látható nagyobb ugrás a már korábbiakban bemutatott tényező következménye: az első 20 körben egyszerre lehetett leadni tippeket. Amennyiben egy játékos nem töltött ki valamennyi eredményt, de adott le érvényes tippet valamely mérkőzésre, úgy a még nem lejátszott és nem megtippelt mérkőzésekre a szoftver automatikusan 0:0-ás értéket vett fel. A 21. körtől kezdődően már sürübben került fel a mérkőzéskínálat, így az említett hatás bekövetkezési esélyei jelentősen csökkentek. A grafikonon a minimum 21 és attól több tippelést megkövetelő korrelációs adatok pedig már egyáltalán nem tartalmazzák az első 20 kör esetleges torzításait. 
A grafikonon látható görbe az 58. értékig értelmezhető, mivel az SPSS vizsgálat során kimutatott kétoldali szignifikancia sorban szereplö értékek kisebbek (egészen az 58. sorig), mint 0,05 , tehát esetükben elvethetjük azt a nullhipotézist, hogy a két változó közötti kapcsolat a véletlennek köszönhető.

Efelett azonban (59+ mérkőzés) a kapcsolat megléte nem bizonyítható, tehát ezeket gond nélkül használhatjuk közös vizsgálatban a számítások során. Ennek megfelelően a továbbiakban n=215 elemszámmal dolgoztam.

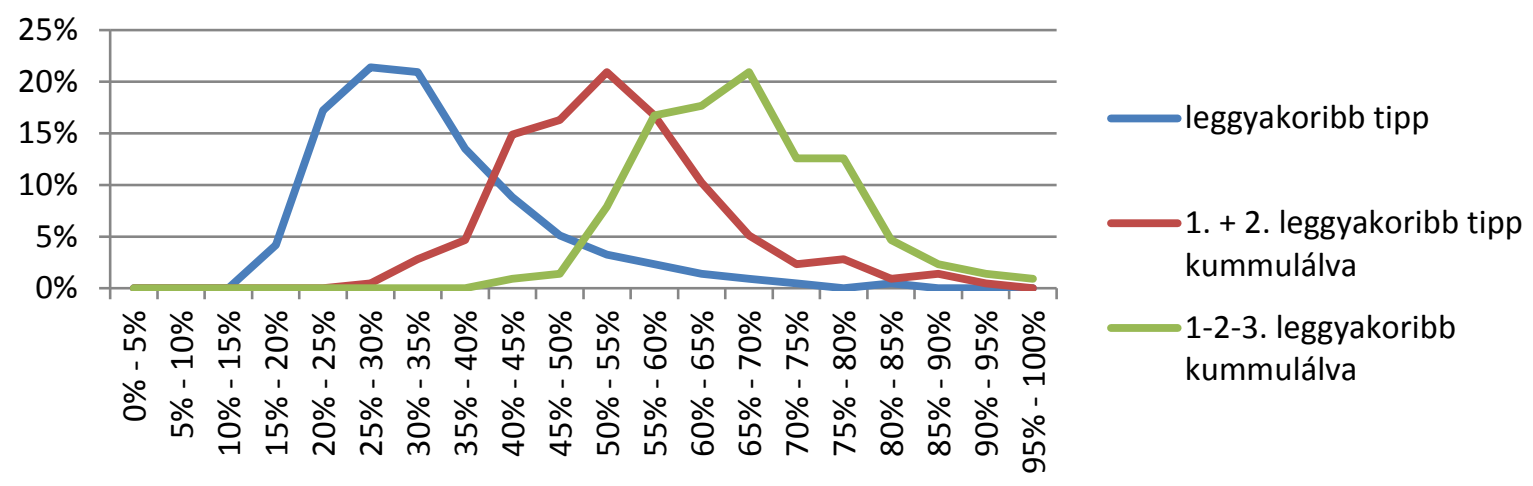

\section{5. ábra: A játékosonkénti 1,2, illetve 3 leggyakoribb tipp kumulált arányainak eloszlása (x tengely: tipp gyakoriságok előfordulási arányai, y tengely: játékosok aránya a tipp gyakorisági skálákhoz tartozóan)}

Forrás: saját mérés, SPSS programcsomaggal

Az 5. ábrán lényegében eloszlási görbéket láthatunk a leggyakoribb, az első két leggyakoribb és az első három leggyakoribb tippek esetében. A grafikonokhoz csak azokat a játékosokat vettem figyelembe, akik legalább 59 mérkőzésre tippeltek $(n=215)$. Ez alapján megállapítható, hogy a játékosok többsége a leggyakoribb tippjét az összesen leadott tippekhez viszonyítva 2035\% közötti arányban alkalmazta (a játékosok 73\%-a). Ha az első két leggyakoribb tippet játékosonként összeadjuk és viszonyítjuk az összes leadott tipphez, akkor a vizsgált létszám esetében az látható, hogy a játékosok 69\%-ának összesen leadott tippjeinek 40-55\%-át fedi le a kettő, leggyakrabban alkalmazott tippje. Az első három tippre az előző kettőhöz hasonló analógián azt kapjuk, hogy a játékosok 80\%-a az összes tippjeinek az 55-75\%-át fedi le a három legsürübben alkalmazott tippjével.

A leggyakoribb tipp előfordulásai átlagosan játékosonként a játékos leadott tippjeinek a 33,7\%át teszi ki, kumulálva a két leggyakoribb tipp összes előfordulását, átlagosan a leadott tippek $53,2 \%$-át teszi ki, és a 3 leggyakoribb tipp összes elöfordulása átlagosan játékosonként a játékos leadott tippjeinek 66,8\%-át teszi ki.

A különböző tippek átlagos száma a legalább 59 tippet leadók körében 9,25 volt, a szórás 1,8. Ennek megfelelően azt mondhatjuk a Pareto arányok analógiáján, hogy átlagosan véve a különbözö tippek egyharmada az összes tipp között kétharmados arányban fordult elö.

Ez a fejezet összességében azt mutatta meg, hogy a játékosok hajlamosak kevésszámú tippvariációban gondolkodni. 


\section{A fogadó irodák becslésére támaszkodva elérhető pontszám}

Mi számít a játékban kockáztatásnak? Amikor a legmagasabb valószínűséggel rendelkező várható eredménytől eltérő tippet ad le egy játékos. Kinek éri meg kockáztatni? Az első helyezettnek értelemszerüen nem éri meg, hiszen ha az utána lévő játékosokkal azonos eredményt tippel, akkor a közöttük lévő távolságot, és ezzel a pozícióját megtartja. Az első helyen álló játékosnak tehát azt kell megtippelnie, amely a többi játékos által elvárt stratégia. Ez pedig a fogadóirodák által várt eredmény (amely nyerés esetén a legkevesebbet fizető oddsszal rendelkezik). Ennek fényében érdemes megnézni, hogy ha valaki végig a fogadóirodák által várt eredményt tippeli a játék során, hány pontot gyüjtött volna.

Amennyiben a játékos a fogadóirodák által „várt” eredményeket követte, úgy célszerű volt aszerint optimalizálnia a döntését, hogy a várható legmagasabb pontszámot érje el. Ez azt jelenti a gyakorlatban, hogy nem mindig a legvalószínűbb eredményt tippelte ezzel a stratégiával a játékos, hanem azt, amely nem telitalálatos tipp mellett is minimalizálta a pontveszteséget. A mérkőzésenként kialakuló optimális tipp tehát az egyes események bekövetkezési valószínűsége és az elérhető pontok kombinációjából alakult ki, miszerint a legnagyobb várható értékkel rendelkező mérkőzés eredményt volt célszerü megtippelni. Az a játékos, aki vakon követte volna ezt a stratégiát a begyüjthető 640 pont 41,1\%-át szerezte volna meg, azaz 263 pontot. Ez a stratégia nagymértékben $(95,3 \%)$ preferálta a valamelyik csapat győzelmével végződő eredményeket, illetve azon belül is szinte kizárólag $(98,4 \%)$ az egygólos sikereket. A leggyakoribb várt eredmény valamelyik csapat 2:1-es győzelme $(54,7 \%)$, majd valamelyik csapat 1:0-s győzelme $(39,1 \%)$. Ezen kívül három darab 1:1-es döntetlen $(4,7 \%)$ és egy darab 2:0-s siker $(1,6 \%)$ volt várható a legmagasabb pontértékkel a tippjátékban.

\section{A játékosok kockázatvállalása}

A rendelkezésre álló adatokból kiszürtem az inaktív játékosokat, hogy ne torzítsák az aktív játékosokra vonatkozó elemzéseket. Inaktívnak tekintettem azokat a játékosokat, akik 40-nél kevesebb tippet adtak le, függetlenül attól, hogy a 40 tippel hány pontot értek el. Ezt követöen az aktívnak tekintett játékosok $(\mathrm{n}=277 \mathrm{db})$ pontjait úgy vettem fel egy hisztogramon, hogy a legkisebb (68 pont) és a legnagyobb (312 pont) között 10 egyenlö léptékü ( $\mathrm{h}=24$ pont) osztályt alakítottam ki. Így a pontokat 68 és 317 között tudtam ábrázolni (az x tengelyen az osztályközök alsó határai láthatóak) (6. ábra).

Az ábrán egy jobb oldalú aszimmetrikus normál eloszlás látható, mely esetén az átlag 219 pont, a medián 227 pont. A fogadóirodák legjobb esélyeit követve a játékosok 263 pontot szerezhettek volna, mégis a játékosok döntő többsége ez alatt teljesített, így azt kell feltételeznem, hogy:

(1) az aktív játékosok inkább kockázatkedvelő magatartásúak voltak és a kockázatvállalásuk általában negatív kimenetelü eredményt hozott, vagy

(2) a mintában szereplő a szó szoros értelmében vett aktív játékosok (mind a 64 mérkőzésre tippelők) további torzítást jelentenek az eredményeknél.

Ezt az utolsó feltételezést vizsgáltam a 6. ábrán látható módon. 


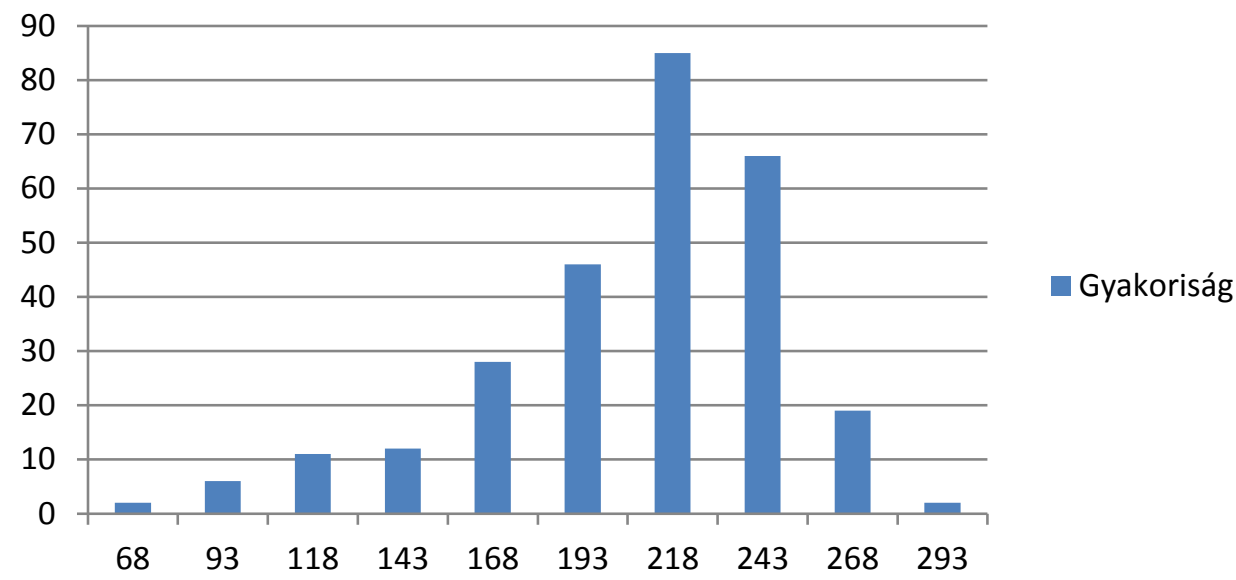

Forrás: saját mérés

6. ábra: Aktív játékosok pontszámai (10 osztály, osztályköz: 24 pont)

A 7. ábrán a valóban aktív játékosokat szemléltetem, akik mind a 64 meccsre adtak le érvényes tippet $(n=131 \mathrm{db})$. Ezen már egy szimmetrikus normál eloszlású görbe (átlag=240 pont, medián=241 pont) rajzolódik ki, tehát e játékosok között valóban voltak jobbak, és kevésbé jobbak, voltak, akik sokkal jobban tippeltek, mint mások.

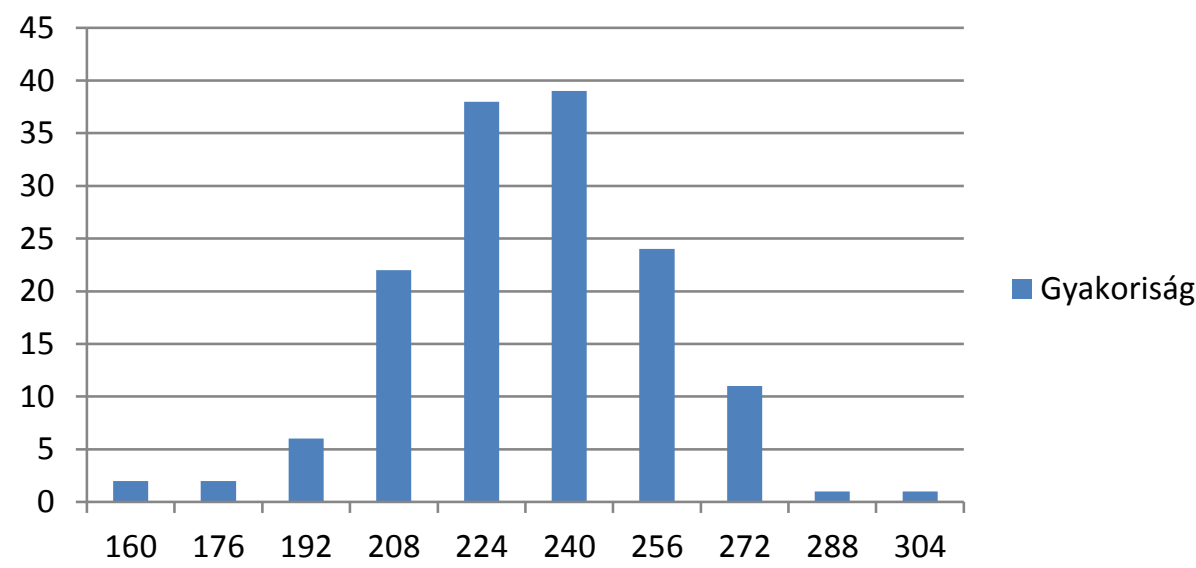

7. ábra: 64 tippet leadók pontszámainak gyakorisága (10 osztály, osztályköz: 24 pont) Forrás: saját mérés

Esetükben az átlag és medián értékek szintén a sport fogadóirodák várható értéke alatt marad, tehát valóban igaz, hogy a játékosok a tippverseny során hajlandóbbak voltak kockázatot vállalni és a kockázatvállalásuk általában negatív kimenetelü eredményt hozott.

\section{A választott kedvenc csapat befolyásoló ereje}

Az előző fejezetekben láthattuk, hogy a fogadóirodákat vakon követve 263 pont lett volna elérhető, mégis a játékosok átlagos teljesítménye elmaradt ettől (240 pont). Vajon miért nem gyüjtött minden játékos 263 pontot? Mi írja felül a racionálisnak tünő megoldásokat? Érzelmi alapon dőlnek el ezek a kérdések? A lehetséges befolyásoló tényezők közül csak azt az esetet vizsgáltam, hogy a kedvenc csapat játéka mennyire befolyásolta a tippeket, mivel a játék adottságainak megfelelően erről rendelkeztem információval.

A kedvenc csapat hatásának mérhetősége viszonylag egyszerüen kivitelezhető, mivel a VB kezdete előtt megkérdezésre kerültek a játékosok, hogy ki lesz a VB győztese. Ugyan ez nem 
feltétlenül jelenti azt, hogy a kiválasztott csapat az adott játékos kedvence is, csupán azt, hogy a VB elött az adott csapatot tartotta a VB-győzelemre legesélyesebb csapatnak. A végső győztes eltalálása ezen kívül 35 pontot is ért a játékosoknak (ha a döntőben veszít: 15 pont, ha csak elődöntőig jut: 5 pont), így racionálisnak tekinthető az a magatartás, ha szurkol az adott csapat győzelmeinek a játékos, hiszen így juthat el a döntőig. A szurkolással azonban mindenképpen kialakul egy érzelmi kapcsolat, amely a racionális döntést torzíthatja.

A rendelkezésre álló csapat-preferenciát tehát össze kell hasonlítani az adott csapat mérkőzéseinél, hogy a semleges és az érintett szurkolók tippjei (győzelem, döntetlen, vereség) milyen hasonlóságot vagy eltérést mutatnak. Itt figyelembe kellett venni, hogy a „más csapatoknak szurkolók" kategóriába nem kerülhetnek az adott meccsen a végső győztesnek az ellenfelet választók, tehát a kvázi „,semleges szurkolók” alkothatják csak a kontroll csoportot.

Mielött lefolytattam volna a vizsgálatot, nagyjából olyan vélemény alakult ki bennem, hogy a dolláraukcióhoz (Shubik, 1971) hasonlóan a játékosok majd ebben az esetben sem akarják realizálni veszteségüket. Ezért abban az esetben sem fognak a választott csapat vereségére tippelni, amikor ez indokolt lenne (az oddsok alapján), hiszen az azt jelentené, hogy a végső győzelemért járó 35 pont elvesztése mellett tippelne a játékos. Ennek fényében azt valószínüsítettem, hogy a saját csapat irányában a győzelmek a várható értékhez képest felül, míg a vereségek jelentősen alul ${ }^{5}$ lesznek reprezentálva a kontrollcsoporthoz képest, és inkább döntetlent tippelnek majd a választott csapat győzelmében bizonytalanok.

A vizsgálat lefolytatásához az elődöntők mérkőzéseit választottam ki, hiszen ezeken a meccseken jórészt kiélezett párharcok voltak, és olyan csapatok szerepeltek, amelyeknek elegendő mennyiségü játékos szurkolt ahhoz, hogy értelmezhető méretü csoportokat állítsak fel. Ugyanakkor a játék vége felé a kezdeti nagy játékos szám miatt ez csak a német-brazil ágra volt igaz. Ezért megnéztem, hogy mely csapatok voltak még egyértelmüen favoritok a VB előtt a játékosok szerint. Ez alapján a brazilok és németek mögött 3. legnépszerübb nemzeti tizeneggyel, a spanyolokkal volt még érdemes foglalkozni. Ök mivel nem jutottak tovább a csoportkörböl, ezért megvizsgáltam a csoportkörös mérkőzéseiket.

Az elödöntős mérkőzések a Brazília - Németország (61. mérkőzés) és a Hollandia - Argentína (62. mérkőzés) párharcok voltak.

A brazil - német mérkőzésre 265 érvényesen leadott tipp érkezett, közülük 47-en Németországot jelölték meg a VB favoritjának, 88-an a brazilokat, így a maradék 130 tippelő alkotja ebben az esetben a kontrollcsoportot.

\section{5. táblázat: A különböző kimenetekre tippelések száma és aránya a mérkőzésben való érintettség függvényében a Brazília Németország találkozó esetében}

\begin{tabular}{|l|c|c|c|}
\hline & Brazília nyer & döntetlen & Németország nyer \\
\hline semleges & $18(14 \%)$ & $59(45 \%)$ & $53(41 \%)$ \\
\hline német & $1(2 \%)$ & $13(28 \%)$ & $33(70 \%)$ \\
\hline brazil & $18(20 \%)$ & $39(44 \%)$ & $31(35 \%)$ \\
\hline
\end{tabular}

Forrás: saját mérés

\footnotetext{
${ }^{5}$ Alig vagy egyáltalán nem vártam vereségre tippelést.
} 
A 3. táblázatban jól látszik, hogy a németek VB-győzelmére tippelők és a brazil végső sikerben bízók is a saját csapatuk irányában tértek el a semleges szurkolók véleményétől. Érdekes azonban, hogy míg korábban úgy véltem, hogy egyáltalán nem lesz olyan játékos, aki a saját csapatának vereségére tippel, ezen a mérkőzésen egyenesen a németeket hozta ki győztesnek a végső győztesnek is Brazíliát tippelő csoport. Ennek fényében tehát az látszik, hogy bár van hatása a korábban meghozott döntésnek, vagy akár érzelmi alapon a csapat-preferenciának, azonban ezeket korlátozott mértékben ugyan, de félre tudjuk tenni és többé kevésbé racionális döntést hozni, bár a semleges szurkolókhoz képest a brazil szurkolók még mindig a saját csapatuk irányában részlehajlóak.

A holland - argentin mérkőzésre 268 tipp érkezett. Argentin szurkolóból 19, hollandból 6, semleges szurkolóból 246 adott le tippet erre a mérkőzésre. Itt az alacsony számok könnyen torzíthatnak, ezért bár az itt kapott számok beleillenek a brazil-német mérkőzésre leadott tippek alapján felállított képbe, azért az eredmények fenntartásokkal kezelendőek.

6. táblázat: A különböző kimenetekre tippelések száma és aránya a mérkőzésben való érintettség függvényében a Hollandia Argentína találkozó esetében

\begin{tabular}{|l|c|c|c|}
\hline & Hollandia nyer & döntetlen & Argentína nyer \\
\hline semleges & $98(40 \%)$ & $106(44 \%)$ & $39(16 \%)$ \\
\hline argentin & $6(32 \%)$ & $7(37 \%)$ & $6(32 \%)$ \\
\hline holland & $4(67 \%)$ & $2(33 \%)$ & $0(0 \%)$ \\
\hline
\end{tabular}

Forrás: saját mérés

3 mérkőzést játszottak a VB-n a spanyolok, kezdjük az elsővel, a spanyol-holland (3. mérkőzés) találkozóval.

\section{7. táblázat: A különböző kimenetekre tippelések száma és aránya a mérkőzésben való} érintettség függvényében a Spanyolország Hollandia találkozó esetében

\begin{tabular}{|l|c|c|c|}
\hline & Spanyolország nyer & döntetlen & Hollandia nyer \\
\hline semleges & $262(51 \%)$ & $209(41 \%)$ & $39(8 \%)$ \\
\hline spanyol & $77(79 \%)$ & $19(20 \%)$ & $1(1 \%)$ \\
\hline holland & $3(27 \%)$ & $6(55 \%)$ & $2(18 \%)$ \\
\hline
\end{tabular}

Forrás: saját mérés

Ezen a mérkőzésen sokkal inkább a vágyak kivetítése látszik, mint a racionalitás, hiszen bár a semleges szurkolók, sőt még a holland szurkolók is a spanyolokat látták esélyesebbnek, a spanyol VB-címre voksolók sokkal nagyobb arányban várták Spanyolország győzelmét.

A 2. meccsüket Chile ellen játszották (19. mérkőzés).

8. táblázat: A különböző kimenetekre tippelések száma és aránya a mérkőzésben való érintettség függvényében a Spanyolország Chile találkozó esetében

\begin{tabular}{|l|c|c|c|}
\hline & Spanyolország nyer & döntetlen & Chile nyer \\
\hline semleges & $409(66 \%)$ & $192(31 \%)$ & $15(2 \%)$ \\
\hline spanyol & $79(77 \%)$ & $22(22 \%)$ & $1(1 \%)$ \\
\hline
\end{tabular}

Forrás: saját mérés 
Ne felejtsük el, hogy a spanyol szurkolók egy nagy csalódáson voltak túl a hollandok elleni nagyarányú vereséggel. Ennek fényében annak ellenére, hogy a semleges szurkolók jóval nagyobb esélyt láttak a hollandok elleni győzelem esélyéhez képest a chilei csapat megverésére, a spanyol VB-címet tippelők közel ugyanolyan esélyt adtak a győzelemre, mint Hollandia ellen. Tették ezt annak ellenére, hogy papíron gyengébb csapat a chilei a hollandnál, és ezt a semleges szurkolók tippjei is alátámasztják.

A záró kört, már tét nélkül az ausztrálok ellen játszották (33. mérkőzés).

\section{9. táblázat: A különböző kimenetekre tippelések száma és aránya a mérkőzésben való érintettség függvényében az Ausztrália Spanyolország találkozó esetében}

\begin{tabular}{|l|c|c|c|}
\hline & Ausztrália nyer & döntetlen & Spanyolország nyer \\
\hline semleges & $42(12 \%)$ & $76(21 \%)$ & $237(67 \%)$ \\
\hline spanyol & $6(10 \%)$ & $11(18 \%)$ & $43(72 \%)$ \\
\hline
\end{tabular}

Forrás: saját mérés

Ami érdekes a spanyol példán, az az, hogy a 3. mérkőzésre már eltűnt a VB-győzelemre leadott tipp befolyásoló ereje, hiszen addigra már biztos volt, hogy nem juthatnak tovább a csoportból, és ez a semleges és spanyol szurkolók tippjeinek összehasonlításán is jól látszik, hiszen már csak nagyon kis különbségü eltérés mutatkozik pozitív irányban a semleges szurkolók tippjeihez képest. Ez a kis különbség tekinthető tulajdonképpen hibahatárnak is, vagy érzelmi befolyásolónak is, hiszen a racionális motiváló hatások eltủntek a tippelés mögül.

Végül a néhány kiemelt példa után a teljes mérkőzéskínálatot és tippmennyiséget is megvizsgáltam. Minden mérkőzés tippeléseit három kategóriára osztottam: hazai szurkolóként érintett tippelők, vendég szurkolóként érintett tippelők és semleges szurkolóként tippelők. Minden kategóriában meghatároztam, hogy milyen a kimenetelek aránya $(1,2, x)$. Végül a 64 mérkőzés esetén átlagot számoltam. Az eredményeket az 10. és 11. táblázat tartalmazza.

\section{0. táblázat: A különböző kimenetekre tippelés aránya a mérkőzésben való érintettség függvényében azok esetében, akik maguk választották ki a "kedvenc" csapatot}

\begin{tabular}{|l|c|c|c|}
\hline & hazai sikerre tippelés & döntetlenre tippelés & vendég sikerre tippelés \\
\hline hazai szurkoló & $58 \%$ & $33 \%$ & $10 \%$ \\
\hline semleges szurkoló & $40 \%$ & $35 \%$ & $25 \%$ \\
\hline vendég szurkoló & $17 \%$ & $21 \%$ & $63 \%$ \\
\hline
\end{tabular}

Forrás: saját mérés

A táblázatban látható az egyértelmű különbség a kontroll csoportnak tekinthető semleges szurkolókhoz képest. Mindkét csoport (hazai és vendég szurkoló) különböző kimenetelekre történő tippelésének átlaga jelentősen eltér, a saját, választott csapat irányában pozitív irányban. 


\section{1. táblázat: A különböző kimenetekre tippelés aránya a mérkőzésben való érintettség függvényében azok esetében, akik kapták (sorsolással) a "kedvenc" csapatot}

\begin{tabular}{|l|c|c|c|}
\hline & hazai sikerre tippelés & döntetlenre tippelés & vendég sikerre tippelés \\
\hline hazai szurkoló & $48 \%$ & $23 \%$ & $29 \%$ \\
\hline semleges szurkoló & $44 \%$ & $22 \%$ & $34 \%$ \\
\hline vendég szurkoló & $38 \%$ & $15 \%$ & $46 \%$ \\
\hline
\end{tabular}

Forrás: saját mérés

Azok, akik a játékhoz annak kezdete után csatlakoztak, nem választottak, hanem kaptak csapatot. Ök sokkal kisebb mértékben voltak részlehajlóak a megkapott csapat iránt, de a hatás az esetükben is megmutatkozott. Ennek jelentősége abban áll, hogy a korábbi, tőlünk független döntéstôl sem tudunk elvonatkoztatni, ugyanakkor kisebb a torzítás, mint amikor a saját korábbi döntésünkhöz ragaszkodunk.

Felvetődött a spanyol mérkőzés kapcsán, hogy a kiesés biztossága gyakorlatilag semleges szurkolókká változtatta az eredetileg spanyol szurkolókat is. Ennek alátámasztására kerestem volna még hasonló csapatot, amely a csoportkörök utolsó fordulójának eredményétöl függetlenül már biztos kiesőnek számított, viszont ezek a csapatok annyira kevés szurkolóval rendelkeztek, hogy a vizsgálatokból származó eredményt egyáltalán nem lehet összehasonlítható és megbízható módon kiértékelni. Ezért ennek vizsgálatára későbbi adatfelvétel lehet indokolt.

Összességében megállapítható, hogy a kedvenc csapatra leadott tippek következetesen eltérnek pozitív irányban a várható eredménytől addig, amíg annak győzelmében vagy továbbjutásában legalább matematikai esély szintjén lehet bízni. Onnantól, hogy a csapat már tét nélkül játszik mérkőzést, csak sejteni lehet, hogy ez a hatás gyengül, ennek megbizonyosodásához további adatfelvétel szükséges. Egy korábbi helyzet mindenkit befolyásol, de amikor a magunk korábbi döntését kell igazolni, akkor még inkább részlehajlóak vagyunk.

\section{A döntések függése más játékosok várható döntéseitöl}

Feltételezésem alapján a játékosok döntései függetlenek egymástól. Ennek a magyarázata abban rejlik, hogy noha van értelme a játékosnak figyelnie a versenytársainak lehetséges lépéseit, azonban a lehetséges versenytársak magas száma miatt nem azonosíthatóak a versenytársak, ezért nem is kerülhet megállapításra, hogy kinek a stratégiájára szükséges reagálni.

Annak érdekében, hogy ez számszerüleg is igazolható legyen, megnéztem, hogy az adott játékosok közvetlen szomszédsága körröl körre hogyan változott. Az egyes játékosok szomszédságába a közvetlen környezetben megtalálható 10 ellenfelet soroltam (ahol erre volt lehetőség, előtte 5, utána 5). A besorolást követően megvizsgáltam, hogy körröl körre hogyan változott ennek a szomszédságnak az összetétele, mennyire volt az állandó. Csak olyan köröket vizsgáltam, ahol az adott játékos adott le döntést, hiszen ha nem adott le, úgy a versenytársakat sem elemezhette. Ennek megfelelöen körröl körre a játékosok környezetének átlagosan 57\%-a cserélődött (azok esetében, akik mind a 64 mérkőzésre tippeltek az arány 54\%). Ha még szükebb környezetet (kevesebb mint 10 ellenfél) veszünk alapul, akkor tovább romlik ez az arány. 
Mindez az alábbit jelentheti. A játékosok szük környezetükhöz képest 43\%-ban hasonló eredményességgel döntenek, míg 57\%-ban ellentétes eredményességgel, mint a környezetük. Ebben az esetben viszont (közel fele-fele arány) a játékosok egyik felével hasonló a döntés, másik felével pedig nem. Annak eldöntése egy szük környezetben, hogy ki a figyelendő ellenfél ennek fényében nehézkes, hiszen már a szük környezetben sem alakul ki egyetértés, így nem határozható meg olyan stratégia, amellyel a szük környezetünkkel szemben egyértelmüen elönyre tudunk szert tenni. A fenti gondolatmenet alapján egyértelmüen csak az lehet a jó stratégia, ha körröl körre a legvalószínübb eseményt tippeljük meg.

A játékosok szük környezete annyira változékony, hogy nem jelölhető ki ellenfél stabilan viszonyítási pontnak, illetve mivel nem képezhető az ellenfelekből homogén csoport, így nem lehet az ellenfelek közvetlen környezetével szemben elönyre szert tenni, még sikeres kockáztatás esetén sem.

\section{Következtetések}

A labdarúgás iránt érdeklődő nők és a férfiak megközelítően azonos eséllyel tippelik meg egy mérkőzés végeredményét.

A tanulmány megmutatta, hogy alapvetően többen érdeklődnek a labdarúgás iránt a férfiak, ami hétköznapi ismereteinkhez képest nem újdonság, azonban fontos tény, hogy a labdarúgást iránt érdeklődő férfiak és labdarúgás iránt érdeklődő nők tippverseny alapján megállapított elörejelző képessége nem különbözik egymástól szignifikánsan.

Amennyiben nincs egymás teljesítményére hatása a játékosoknak, úgy a racionálisan hozott döntések nem függhetnek más játékosok döntéseitöl.

Egy olyan játékban, ahol a játékosok teljesítménye nem egymás teljesítményétől függ, hanem kizárólag külső hatásoktól, abban az esetben a döntéseket nem befolyásolhatja más játékosok várható cselekedete, a várható legnagyobb valószínüségü választási lehetőséget kell választani minden esetben. Amennyiben nem így teszünk, túlzott mértékü kockázatot vállalunk, várható pontveszteséggel a racionálisan döntő ellenfelekkel szemben.

Csökkenő győzelmi esélyek mellett csökken a játékosok aktivitása.

Egy ranglistára épülő versenyben a győzelem eshetősége jelentős motiváló erőt képvisel. Azokban a játékokban, ahol a végső győzelem esélye jelentősen csökken a játékos számára, a játékosok többsége a játék felhagyásával reagál. Amennyiben a győzelem esélyét sikerül valamilyen módon fenntartani, a kilépési arány jelentősen javítható.

A játékosok kisszámú tippvariációban gondolkoztak, kerülve a szélsőséges tippeket.

A 64 mérkőzéses VB-tippjátékban átlagosan 9,25-féle (szórás: 1,8) különböző eredményt adtak le a játékosok. A leadott tippek 2/3-át a 3 leggyakoribb tippel fedték le, azaz a 64-ből 42-43 mérkőzésen mindössze 3 különböző tippet alkalmaztak. A tanulmány eredményei alapján megállapítható, hogy a játékosok általában kisszámú tippvariációban gondolkodnak egy előrejelző játékban és kerülik a szélsőségeket.

A játékosok általában kockázatvállalóak voltak, negatív kimenetellel.

A játékosok (mint tippelésben érdekelt "szakértők") átlagosan gyengébb teljesítményt értek el, mint ha a fogadóirodákra támaszkodva mindig a legvalószínübb eredményt tippelték volna meg. A játékosok ezzel a tippverseny során hajlandóbbak voltak kockázatot vállalni és a kockázatvállalásuk általában negatív kimenetelü eredményt hozott. 
A korábbi döntések befolyásoló ereje a későbbi döntésekre eltér attól függően, hogy a korábbi döntést a játékos saját maga hozta meg, vagy más hozta meg helyette.

A dolgozat fontos, általánosan az életben is használható jelentősége, hogy megmutatja, hogy egy korábbi döntésünk mennyiben befolyásolja a későbbiekben is a döntéseinket. Amíg a korábbi döntésünkben való bizodalmunkat egyértelmúen kizáró esemény nem következik be, úgy a valós bekövetkezési esélyektől nagyobb mértékben hitetjük el magunkkal, hogy az adott esemény be fog következni, túlzott optimizmust táplálva a saját döntésünk sikerét illetően. A dolgozat megmutatta, hogy a saját döntés befolyása számottevő eltérést mutat a függetlenül döntőkhöz képest, ugyanakkor a megteremtett szituációba történő beleülés is eredményez torzítást. Ezt lehorgonyzási heurisztikának hívjuk, mivel a játékosok a korábbi döntést, vagy sorsolást viszonyítási pontként fogadták el. A horgony mindkét esetben müködött, mind a két esetben a korábbi választásnak fontos szerepe volt, azonban az utóbbiban mérsékeltebb volt ennek hatása.

Az eredmények alapján levezethető az a következtetés, hogy egy döntéshozó nem csak akkor lehet képes végigvinni egy korábbi hibás döntést, amikor az a sajátja, de egy, a pozíciót újonnan megkapó személy sem képes függetleníteni magát a korábbi eseményektől teljes mértékben. Ez a döntéshozók időszakos cserélésének egy pozitív hozadékára mutathat rá, természetesen annak kockázatairól most nem beszélve, hogy ha egy ismeretlen területre kerül valaki, az milyen egyéb kockázatokkal járhat.

\section{Irodalomjegyzék}

1. ANDERSSON,P. - EDMAN, J. - EKMAN, M. (2005): Predicting the World Cup 2002 in Soccer: performance and confidence of experts and non-experts. International Journal of Forecasting 21 pp. 565-576.

2. FINTOR,G. J. (2012): A sport és a média kapcsolata a középfokú oktatásban. Poszter bemutató. A tanárok tanárának lenni...Jubileumi konferencia Szabó László Tamás 70. születésnapjára, 2012. szeptember 26., Debrecen

3. FINTOR, G. - SZABÓ, J. (2012):A televíziós sportmüsorok hatása az egyes társadalmi rétegekre, Zempléni Múzsa 2012/1, pp23-29, Zempléni Múzsa Társadalomtudományi és Kulturális Alapítvány, Sárospatak

4. GFK (2014): A háztartások sörvásárlása erőteljesen szezonális, Sajtószolgálat, 2014. június 5 ., online elérhetőség: http://www.gfk.com/hu/documents/20140605_gfk\%20a\%20s\%C3\%B6r-\%C3\%A9s\%2 0snackfogyaszt\%C3\%A1sr\%C3\%B31.pdf [letöltve: 2015.09.14]

5. KAHNEMAN, D. (2011): Thinking, Fast and Slow, Farrar, Straus ang Giroux, New York, magyarul: Gyors és lassú gondolkodás, HVG Könyvek, Budapest, 2013

6. KEYNES, J. M. (1936): The General Theory of Employment, Interest and Money,1936, London: Palgrave Macmillan

7. NASH, J. F. (1950): Equilibrium Points in n-Person Games, Proceedings of the National Academy of Sciences of the United States of America, Vol. 36, No. 1. (Jan. 15., 1950), pp 48-49

8. SHUBIK, M. (1971): The Dollar Auction Game: A Paradox in Nooncooperative Behavior and Escalation, The Journal of Conflict Resolution, Volume 15, Issue 1, pp. 109-111.

9. SPANN, M. - SKIERA, B. (2009): Sports Forecasting: A Comparison of the Forecast Accuracy of Prediction Markets, Betting Odds and Tipsters, Journal of Forecasting, vol. 28., no. 1., pp. 55-72. 